\title{
Osocial e o cultural na obra de Vigotski
}

\author{
Angel Pino Sirgado*
}

\begin{abstract}
RESUMO: Este texto constitui um ensaio de análise de duas categorias teóricas consideradas fundamentais para uma leitura compreensiva da obra de Vigotski : o social e o cultural. O texto toma como ponto de partida o Manuscrito de 1929, onde o autor esboça essas questões, objeto de uma elaboração posterior. A análise do significado que essas categorias têm para Vigotski é feita por meio do conceito de história proposto pelo autor, o qual revela a matriz que lhe serve de referência das suas análises: o materialismo histórico e dialético. Analisadas essas duas categorias, são discutidas duas questões decorrentes delas e que constituem o núcleo central da obra do autor: a natureza social-cultural das funções mentais superiores que, segundo o autor, são relações sociais internalizadas, e o mecanismo semiótico que explica a conversão dessas relações sociais em funções da pessoa.
\end{abstract}

Palavras-chave:

What is man? For Hegel, he is a logical subject.

For Pavlov, it is a soma, an organism. For us, man is a social person: an aggregate of social relations, embodied in an individual. (Vygotsky, "Concrete Human Psychology")

A leitura, pela primeira vez, do "Manuscrito" de Vigotski, publicado em inglês sob o título "Concrete Human Psychology", evocou em mim

* Professor da Faculdade de Educação da Universidade Estadual de Campinas (Unicamp). E-mail: apino@obelix.unicamp.br. 
a estranha lembrança de uma experiência vivida no museu de Madrid, quando, também pela primeira vez, fui ver o Guernica, esse monumento de arte erguido pelo gênio de Picasso contra o horror nazista. Atravessando a galeria que conduzia ao salão principal onde estava exposto o famoso quadro, chamou-me a atenção a seqüência de esboços que tapizavam as paredes. Cada esboço era um detalhe da obra maior e cada detalhe uma obra de arte em escala menor. De detalhe em detalhe, eu ia me aproximando do salão principal, ao mesmo tempo que ia penetrando pouco a pouco na significação da obra do pintor.

Procurando a razão da estranha evocação, percebi que o que provocara a associação da leitura do "Manuscrito" com a experiência do museu era a relação entre os detalhes e a obra. À semelhança da impressão causada pela seqüência dos detalhes do Guernica expostos na galeria, a leitura do "Manuscrito" de Vigotski deu-me a impressão de estar em outra galeria onde estava sendo exposta uma seqüência de detalhes, idéias apenas esboçadas, de uma obra maior. Em ambos os casos, cada detalhe constituía uma obra em si mesmo e o segredo da compreensão do pensamento de cada autor parecia-me estar em encontrar o lugar do detalhe na obra e em descobrir a obra nos seus detalhes.

Ao ler pela primeira vez o "Manuscrito", tive a sensação de ter de enfrentar um desafio nada fácil: descobrir nos detalhes o sentido de uma obra maior que a morte prematura do autor deixou, certamente, inacabada. O presente trabalho faz parte de um esforço continuado para enfrentar esse desafio. Meu objetivo é procurar o sentido do pensamento do autor num desses detalhes que mais chamou a minha atenção e que, em razão disso, aparece como epígrafe deste texto: "Para nós - diz Vigotski - o homem é uma pessoa social. Um agregado de relações sociais encarnadas num indivíduo ".

\section{Uma questão preliminar}

Uma vez enunciada por Vigotski a "lei genética geral do desenvolvimento cultural" (1989, p. 58; 1997, p.106), segundo a qual toda função psicológica foi anteriormente uma relação entre duas pessoas, ou seja, um acontecimento social, pode-se afirmar que o social e o cultural constituem duas categorias fundamentais na obra do autor. Porém, o tratamento dado por ele a estas categorias, não precisando suficientemente a sua signifi- 
cação, deixa uma boa margem à interpretação do leitor. Com efeito, o caráter excessivamente genérico do termo social e do termo cultural não permite que esses conceitos possam fundamentar um modelo de desenvolvimento humano tal como o proposto por Vigotski, a menos que sejam devidamente circunscritos no contexto teórico em que eles são utilizados. O termo social, visto que ele é um conceito que qualifica formas de sociabilidade existentes no mundo natural, não permite por si só explicar formas de organização social que extrapolam o campo dos fenômenos naturais, como é o caso da sociabilidade humana. Quanto ao termo cultural, trata-se de um conceito entendido e utilizado pelos autores de formas diferentes, o que exige que seja devidamente conceitualizado no contexto próprio em que é utilizado por Vigotski. Especificar bem este termo é fundamental para precisar o outro, uma vez que a existência social humana pressupõe a passagem da ordem natural para a ordem cultural. Discutir a natureza do social e a maneira como ele se torna constitutivo de um ser cultural é, sem dúvida alguma, um detalhe muito importante da obra de Vigotski, o qual merece uma atenção especial.

Uma vez que o autor não especificou suficientemente o sentido que o social e o cultural têm para ele, qualquer tentativa de determinar esses sentidos exige que sejam situados no contexto teórico em que são utilizados. Determinar tal contexto constitui o que estou chamando de questão preliminar, ou seja, uma questão que nos permita determinar o sentido que esses conceitos têm para o autor. Isto é ainda mais necessário uma vez que as características peculiares do "Manuscrito" tornam sua leitura particularmente difícil.

Esta tarefa nos é facilitada pelo próprio autor com a nota sintética e quase lapidar com a qual ele abre o "Manuscrito" - nota na qual define o sentido que o termo história tem para ele (1989, pp. 54-55). Para um leitor menos atento, essa nota pode passar meio desapercebida ou causar-Ihe um certo estranhamento por figurar no início do "Manuscrito". Lida, porém, com atenção, percebe-se que a questão da história é uma questão-chave na análise da natureza do social e do cultural na obra de Vigotski.

É difícil dizer qual a razão levou o autor a colocar essa nota no começo do "Manuscrito". Certamente deve ter tido alguma. Pode-se conjeturar que a questão da história era tão importante para ele que destacá-la em forma de nota introdutória poderia servir como lembrete de algo que não poderia esquecer nas análises posteriores. Sim, porque nada indica que ele imaginava que um dia as suas anotações seriam publicadas. Pode-se pensar então que, uma vez tornadas públicas tais anotações, o 
que era um lembrete torna-se para o leitor também um lembrete de algo que não pode esquecer, se quiser entender o sentido das idéias expostas no "Manuscrito".

A questão da história é fundamental porque nos remete à matriz que constitui o contexto do pensamento de Vigotski. É o caráter histórico que diferencia a concepção de desenvolvimento humano de Vigotski das outras concepções psicológicas e lhe confere um valor inovador ainda nos dias de hoje, sete décadas após a redação do "Manuscrito". Podemos portanto afirmar que a questão da história, tal como aparece em Vigotski, permite definir os contornos semânticos do social e do cultural e é uma questão-chave no debate da relação entre natureza e cultura.

História é entendida por Vigotski de duas maneiras ${ }^{1}$ : em termos genéricos, significa "uma abordagem dialética geral das coisas"; em sentido restrito, significa "a história humana". Distinção que ele completa com uma afirmação lapidar: "a primeira história é dialética; a segunda é materialismo histórico". Podemos afirmar então, com bastante segurança, que a nota que abre o "Manuscrito" define o lugar de onde Vigotski fala e a matriz que lhe serve de referência nas suas análises: o materialismo histórico e dialético. Consideramos isto de suma importância, pois nos dá o perfil do autor como pensador da natureza humana, constituindo o núcleo duro da sua obra.

A razão de Vigotski não se estender na análise da questão levantada por essa nota introdutória pode ser a de que ele considerasse essa questão suficientemente familiar aos seus conterrâneos e contemporâneos, leitores de Marx e Engels. De forma alguma isso quer dizer que seja uma questão marginal nos seus escritos. Muito pelo contrário, ela é fundamental pois confere coerência lógica ao conjunto das suas obras. Poder-se-ia dizer que é o eixo central delas, em particular de algumas, como a obra dedicada à análise do significado histórico da crise da psicologia (Vygotsky, 1996) - em que afirma a necessidade de a psicologia construir o seu próprio $O$ capital para poder sair da crise - e a consagrada à análise da história do desenvolvimento das funções mentais superiores (Vygotsky, 1997). É interessante observar na primeira dessas duas obras que, muito antes que Althusser estabelecesse a diferença entre "materialismo histórico" ou ciência da história e "materialismo dialético" ou filosofia marxista (1969, p. 33), Vigotski já fazia referência a essa distinção, ao identificar-se com o ponto de vista de Vichnievski quando, na sua polêmica com Stepánov, sustenta que "o materialismo histórico não é o materialismo dialético, mas sua aplicação à história” (1996, p. 393). 
A nota de Vigotski sobre o significado do termo história acaba colocando sobre a mesa de discussão duas questões interligadas. Uma delas é a diferença existente entre a concepção de materialismo de Marx e Engels e outras concepções existentes na sua época. Neste caso, o divisor de águas entre essas concepções é o caráter histórico ou não do materialismo. Outra, é a diferença que existe entre a concepção da dialética em Marx e Engels e em outros autores, em particular em Hegel. Aqui o divisor de águas é o caráter materialista da dialética daqueles e idealista deste último. É o caráter histórico que define o materialismo de Marx e Engels e é o caráter materialista que define a sua dialética. Como é fácil de perceber, trata-se de uma problemática complexa cuja análise mais profunda escapa aos objetivos deste trabalho, mas, dada a sua importância, não pode ser passada por alto. Assim, limitar-me-ei a fazer algumas breves considerações a respeito dela, considerações minimamente necessárias para a finalidade deste trabalho.

Como vimos anteriormente, a nota de Vigotski estabelece uma relação dupla no significado de história: de um lado, com a dialética, do outro, com o materialismo histórico. Mas na medida em que o materialismo histórico é a aplicação do materialismo dialético à história, como afirma o autor nas palavras de Vichnievski, a nota de Vigotski nos remete, ao mesmo tempo, ao que Althusser chama de ciência da história, um modo de entender os acontecimentos que formam a história, e de filosofia marxista, instrumento gnosológico de análise da história.

Quando Vigotski fala do significado geral de história, apoia-se na célebre afirmação de Marx - "a única ciência é a história" - para esclarecer aquilo que está afirmando. Esta referência nos autoriza a pensar que, se a história é a única ciência, deve ser porque toda ciência é necessariamente histórica. Mas dizer que a ciência é histórica, no contexto do materialismo histórico, equivale a dizer que ela é produto da atividade humana, não um dado puro da razão nem a simples expressão da realidade natural das coisas. Como qualquer produção humana, a ciência está ligada às condições da sua produção. Em termos gerais, pode-se dizer que a ciência é a natureza pensada pelo homem que, dessa maneira, passa a integrar a história humana na forma de ciência da natureza. A natureza em si mesma não tem história. Embora Vigotski não nos forneça maiores informações a respeito da afirmação de Marx, ao trazê-la como exemplo do que ele quer dizer, está afirmando que o conhecimento é um processo histórico que segue as leis da dialética. Mas que dialética? A referência a Marx e Engels mostra que 
está falando da dialética materialista que Marx contrapõe à dialética idealista de Hegel e seus seguidores.

Como o mostra a análise de Althusser (1969), não é coisa fácil estabelecer a diferença entre materialismo histórico e materialismo dialético, uma vez que essas duas disciplinas, como ele as denomina, embora tenham objetos diferentes - os modos de produção, no materialismo histórico, e a história da produção do conhecimento, no materialismo dialético - estão interligadas pois cada uma delas abrange questões relativas à outra. Além disso, não existe, no que concerne a esta segunda disciplina, o materialismo dialético, algo equiparável à elaboração teórica de $O$ capital, obra em que Marx estabelece os princípios do materialismo histórico.

Sem querer ir além neste tema, cabe lembrar, com Althusser, que, se o objeto do materialismo dialético ocupa o campo da "teoria do conhecimento" da filosofia clássica, o faz de forma muito diferente: no lugar de ser uma teoria das condições formais, intemporais e a-históricas da produção do conhecimento - como a filosofia do "cogito" (Descartes, Husserl), das "formas a priori" (Kant) e do "saber absoluto" (Hegel) - é, ao contrário, uma teoria das condições reais, materiais e sociais, da sua produção (1969, p. 43). O materialismo dialético não é só método, como pode dar a entender uma leitura pouco atenta da nota de Vigotski. Ele é também uma teoria, ou seja, um complexo conceptual que permite pensar um objeto. É teoria e método, como elementos interligados e aspectos diferentes de uma mesma realidade. Não só teoria, pois não escaparia do dogmatismo das teorias clássicas da filosofia do conhecimento. Não só método, pois perderia o estatuto de ciência que precisa de um objeto.

Como diz Althusser, "no materialismo dialético pode-se considerar, esquematicamente, que é o materialismo o que representa o aspecto da teoria, enquanto que a dialética representa o aspecto do método" (1969, p. 46). Um remete ao outro. É o materialismo que confere à dialética seu caráter histórico, pois expressa os princípios das condições concretas da produção do conhecimento, ou seja: (a) a distinção entre o real e o conhecimento desse real e (b) a primazia do real sobre o conhecimento. O primeiro desses princípios, além de permitir escapar das concepções racionalistas e empiricistas, implica no fato de que entre o real e o conhecimento desse real existe um distanciamento em que opera a atividade produtiva do sujeito. O segundo faz do real o ponto de partida do conhecimento, não de chegada como decorre do idealismo hegeliano - mas um ponto de partida que não se perde no processo de produção do conhecimento. $O$ objeto de 
conhecimento não é o real em si, tampouco um mero objeto de razão. Ele é o real transformado pela atividade produtiva do homem, o que the confere um modo humano de existência.

A questão preliminar, ao oferecer uma teoria da história do homem e do mundo no homem, instrumentaliza-nos para analisar o problema da relação natureza/cultura. Este é um problema de fundo nas análises que Vigotski faz das funções elementares ou naturais e das funções superiores ou culturais e da sua articulação na unidade da pessoa. Em termos bem gerais, esse problema pode ser assim colocado: na evolução das espécies ocorre um momento de ruptura quando a espécie homo desenvolve novas capacidades que lhe permitem transformar a natureza pelo trabalho, criando suas próprias condições de existência. Isto, por sua vez, permite ao homem transformar seu próprio modo de ser (cf. Marx, 1977, I, cap. 7; Marx \& Engels, 1982, pp. 70-71). Esse momento de ruptura não interrompe o processo evolutivo mas dá ao homem o comando da própria evolução. A história do homem é a história dessa transformação, a qual traduz a passagem da ordem da natureza à ordem da cultura. Ao colocar a questão da relação entre funções elementares ou biológicas e funções superiores ou culturais, Vigotski não está seguindo, como o fazem outros autores, a via do dualismo. Muito pelo contrário, ele está propondo a via da sua superação. As funções biológicas não desaparecem com a emergência das culturais mas adquirem uma nova forma de existência: elas são incorporadas na história humana. Afirmar que o desenvolvimento humano é cultural equivale portanto a dizer que é histórico, ou seja, traduz o longo processo de transformação que o homem opera na natureza e nele mesmo como parte dessa natureza. Isso faz do homem o artífice de si mesmo.

A referência de Vigotski aos dois sentidos de história revela também sua preocupação em articular os dois planos: o ontogenético, história pessoal, e o filogenético, história da espécie humana. Tal parece ser o sentido da afirmação que encerra a nota introdutória do "Manuscrito": "A singularidade da mente humana está no fato de que os dois tipos de história (evolução + história) estão unidos (síntese) nela. O mesmo é verdadeiro na psicologia da criança"². A história pessoal (desenvolvimento cultural), sem deixar de ser obra da pessoa singular, faz parte da história humana. A transformação que ocorre no plano ontogenético é um caso particular da que ocorre no plano filogenético. Não ter entendido isso ou o ter ignorado constitui, segundo Vigotski, um dos maiores equívocos dos trabalhos em psicologia do desenvolvimento da criança (1997, pp. 1-26). 
Uma vez esclarecida a questão preliminar, ou seja, o sentido que o conceito de história tem para Vigotski e o papel que esse conceito desempenha na matriz do materialismo histórico e dialético, contexto referencial do autor, cabe agora analisar a maneira como esse conceito permite especificar o sentido do social e do cultural. Seguindo as pistas deixadas pelo autor no "Manuscrito", tentarei abordar, inicialmente, a questão do social e sua relação com o cultural, para, em seguida, abordar a questão do desenvolvimento cultural tal como proposto por ele.

\section{Sentido do social}

O termo "social" é um dos termos mais freqüentemente usados por Vigotski nos seus trabalhos. Ele aparece em diferentes momentos, lugares e contextos. O que não é de se estranhar, pois é o princípio da natureza e origem sociais das funções superiores que constitui a marca da nova concepção de desenvolvimento psicológico que ele introduz em psicologia. Princípio com o qual ele se coloca na contramão do pensamento psicológico da sua época e, seguramente, também da nossa. A história da psicologia mostra, com efeito, que dificuldade ela tem para tratar a questão da dimensão social do indivíduo. Mesmo nesse setor da psicologia geral denominado psicologia social, que dificuldade para definir o que é e o que não é social no comportamento; o que é obra do indivíduo e o que é resultado da ação do meio social. Essa dificuldade se reflete no caráter vago de conceitos tais como "socialização", "adaptação social", "crise" etc. usados no tratamento teórico da inserção da criança/adolescente no meio social. Se o desenvolvimento é visto como um acontecimento de natureza individual, mesmo admitindo que ocorre em interação com o meio, a inserção social do indivíduo constitui realmente um problema, pois implica na adaptação das condutas individuais às práticas sociais, consideradas, em tese, fenômenos de natureza diferente. Dessa maneira, a socialização assemelha-se ao fenômeno migratório humano que exige uma adequação das características sociais e culturais do imigrante às condições do novo meio. Vigotski inverte a direção do vetor na relação indivíduo-sociedade. No lugar de nos perguntar como a criança se comporta no meio social, diz ele, devemos perguntar como o meio social age na criança para criar nela as funções superiores de origem e natureza sociais (cf.1989, p. 61). Questão que o autor retoma em outro texto posterior, no qual afirma explicitamente: "Em contraposição a Piaget, pensamos que o desenvolvi- 
mento segue não no sentido da socialização mas no da conversão das relações sociais em funções mentais" (1997, p. 106, itálico meu). Isso não quer dizer que os problemas que essa afirmação levanta estejam resolvidos, mas mostra o caminho da sua solução escapando da armadilha do dualismo, à condição, bem entendido, de mostrar o mecanismo mediador que explique a conversão do social em pessoal sem tirar ao indivíduo sua singularidade. Esse mecanismo, do qual tratarei mais adiante, é a mediação semiótica. Tê-lo indicado é um dos grandes méritos de Vigotski.

Embora o autor use o termo "social" com freqüência, deve-se reconhecer que, como ocorre com outros conceitos-chave, não aprofunda sua definição, problema deixado aos seus leitores. O que ele faz é apontar situações ou fatos aos quais, segundo ele, se aplica o caráter social. (1989, p. 58; 1997, pp. 106-107). Neles, Vigotski estabelece três tipos de relações interessantes: 1) entre o social e o cultural ; 2) entre o social e o simbólico; e 3) entre o social e as funções mentais superiores. Essas relações colocam outras tantas problemáticas que, analisadas na perspectiva do sentido de história que constitui a questão preliminar, nos dão uma visão global das questões fundamentais da obra de Vigotski.

\section{O social e o cultural}

Num sentido mais amplo, diz Vigotski, "tudo o que é cultural é social", o que faz do social um gênero e do cultural uma espécie. Isso quer dizer que o campo do social é bem mais vasto que o da cultura, ou seja, que nem tudo o que é social é cultural mas tudo o que é cultural é social.

Enquanto expressão das múltiplas formas que pode tomar a sociabilidade, o social é um fenômeno mais antigo que a cultura pois é um dos atributos de certas formas de vida, o que nos permite falar de uma sociabilidade biológica, natural. Anterior à cultura, o social adquire dentro dela formas novas de existência. Sob a ação criadora do homem, a sociabilidade biológica adquire formas humanas, tornando-se modos de organização das relações sociais dos homens. Neste sentido, o social é, ao mesmo tempo, condição e resultado do aparecimento da cultura. É condição porque sem essa sociabilidade natural a sociabilidade humana seria historicamente impossível e a emergência da cultura seria impensável. É porém resultado porque as formas humanas de sociabilidade são produções do homem, portanto obras culturais.

A existência no mundo animal de formas variadas de organização social, em certos casos muito próximas das criadas pelos homens, é um fato 
biológico hoje incontestável. Na lógica do princípio evolutivo, isso faz da sociabilidade animal o substrato da sociabilidade humana, como a natureza é o substrato e a condição de emergência da cultura. Mas, contrariamente ao que ocorre no mundo biológico, a sociabilidade humana não é simplesmente dada pela natureza, mas assumida pelo homem que procura formas variadas de concretizá-la. Estas formas circunscrevem o campo do que entendemos por organização social ou sociedade. O homem cria suas próprias condições de existência social da mesma forma que cria suas condições de existência material. Por serem obra do homem, estas condições de existência social ou formas de sociabilidade humana, das mais simples das sociedades tribais às mais complexas das sociedades contemporâneas, integram o elenco do que denominamos produções culturais. Mas o que é a cultura?

Não sendo objetivo deste trabalho analisar especificamente a questão da cultura, assunto de outro texto em vias de publicação (Pino 2000), não entrarei na discussão desta questão, onde a polissemia do termo se mistura com as concepções diferentes de mundo e de homem que permeiam a história do pensamento humano. Limito-me aqui à afirmação de que, de maneira sintética, Vigotski define a cultura como "um produto, ao mesmo tempo, da vida social e da atividade social do homem" (1997, p. 106). Ao distinguir entre produto da "vida social" e produto da "atividade social", levando-se em conta a matriz teórica em que o autor se situa, podemos pensar no primeiro caso a cultura entendida como prática social resultante da dinâmica das relações sociais que caracterizam uma determinada sociedade e no segundo caso como produto do trabalho social, nos termos em que falam Marx e Engels. Se assim for, para Vigotski a cultura é a totalidade das produções humanas (técnicas, artísticas, científicas, tradições, instituições sociais e práticas sociais). Em síntese, tudo que, em contraposição ao que é dado pela natureza, é obra do homem. Evidentemente, isso não é suficiente para explicar a natureza da cultura. Como aparece em outros textos do autor e na literatura especializada que trata esta questão, a natureza da cultura está relacionada com o caráter duplamente instrumental, técnico e simbólico, da atividade humana.

\section{O social e o simbólico}

Vigotski considera também social "um signo ou símbolo independente do organismo, como no caso do instrumento" (itálico do autor). Deixando de lado a questão menor da discutível identificação que ele parece fazer aqui dos termos "signo" e "símbolo", dois pontos merecem ser destacados nes- 
sa afirmação. Primeiro, a relação que ele estabelece entre o social e o simbólico. Segundo, a condição, aparentemente estranha, que ele coloca para atribuir ao simbólico o caráter social. Quanto ao primeiro ponto, pode-se dizer que, ao equiparar o símbolo ao instrumento técnico, dois conceitos que o autor distingue em outros textos, o que parece estar afirmando é que o símbolo é uma criação do homem, como o instrumento, e, como tal, faz parte da ordem da cultura e não da natureza, tendo assim uma existência independente do organismo. Dessa forma aplica-se a ele o caráter social. Quanto ao segundo ponto, cabe a perguntar: se para ser social o símbolo tem de ser "independente do organismo", existiria um tipo de signo que dependa do organismo? À primeira vista, a condição posta por Vigotski não parece se sustentar, pois por definição o signo é independente do organismo. Mas admitindo que o autor tenha alguma razão para dizer o que diz e que, dessa forma, ele está indicando que existe um tipo de signo dependente do organismo, ou seja, de natureza biológica, podemos supor que ele usa o termo signo num sentido genérico que englobaria dois tipos de signos: os naturais e os artificiais ou produzidos pelo homem.

O estudo mais completo feito por Vigotski sobre o signo é o texto de 1930 (1994), em que é possível seguir quase que passo a passo o processo de elaboração pelo autor desse conceito. Processo difícil e às vezes em ziguezague que pode desorientar o leitor menos atento. A novidade desse texto, como ele mesmo lembra (p.106), é mostrar, pela primeira vez, que o uso de instrumentos técnicos e a atividade com símbolos são dois processos que mantêm entre si relações estruturais e genéticas e que, por isso mesmo, não podem ser tratados como distintos e independentes, tal como vem sendo feito na psicologia. A esse respeito ele diz:

Uma série de observações levarou-nos a assumir que o estudo isolado da inteligência prática e da atividade simbólica está absolutamente errado. Se uma poderia existir sem a outra no caso dos animais superiores, então deve-se concluir logicamente que a união desses dois sistemas é o que constitui a especificidade do comportamento complexo do homem. Resulta daí que o começo da atividade simbólica desempenha um papel específico de organização, penetrando no processo de uso de instrumentos e dando origem às principais formas novas de conduta (ibidem, p. 108).

O que Vigotski está dizendo, com outras palavras, é que a emergência da atividade simbólica constitui, tanto na história da espécie quanto na 
história pessoal de cada indivíduo, o ponto de passagem do plano natural para o plano cultural - planos que na filogênese aparecem separados mas na ontogênese coincidem e se interpenetram (1997, pp. 18-19). Esta é a questão de fundo das análises de Vigotski. A necessidade de mostrar que a função simbólica, como toda função superior ou cultural, tem sua origem numa função natural, leva-o a procurar as raízes genéticas do signo, ou seja, a função natural correspondente. É nessa procura que o modelo da "dupla sinalização" de Pavlov ${ }^{3}$ parece ter fornecido a Vigotski os fios que lhe permitiriam desenrolar o novelo da semiótica. Com efeito, tal modelo, que ele acaba descartando, inspirou os seus primeiros estudos sobre o signo. Neles, o signo desempenha claramente a função de estímulo externo de uma operação interna, como podemos ver nas suas análises sobre a percepção, a atenção e, em particular, a memória (1994, pp. 142-146). No caso específico da memória, o autor distingue dois tipos: a natural e a artificial, mostrando já um princípio de diferenciação entre o sinal como expressão da natureza e o signo como expressão cultural. A memória natural está muito próxima da percepção sensível e é o resultado da ação direta dos estímulos externos sobre o organismo. A memória artificial, por sua vez, é muito mais complexa e funciona através de meios (estímulos) criados pelo próprio indivíduo; por exemplo, servir-se de uma fita no pulso para lembrar de um compromisso assumido. Neste caso, entre o estímulo natural e a resposta $(E<>R)$ interpõe-se um estímulo ou meio artificial $(\mathrm{X})$, denominado pelo autor "estímulo de segunda ordem", que desempenha uma função totalmente nova, diferente de tudo o que foi observado nas formas elementares de conduta.

Esta função é mostrada na figura 1, proposta por Vigotski:

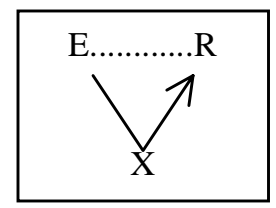

Figura 1: mediação do estímulo de segunda ordem

onde a relação natural e direta "E.....R" é inibida pela ação do estímulo artificial $(X)$, o qual passa a monitorar a resposta $(R)$ do indivíduo. Esse estímulo, diz ele, é carregado para o interior da operação (da memória, ou de qualquer outra função), desempenhando o papel de organizador 
da resposta. Com ele o indivíduo controla sua própria ação. É a este estímulo que ele chama de "signo", "dando a este termo um sentido, ao mesmo tempo mais amplo e mais preciso que no uso comum" (1997, p. 54). Com efeito, ele está se referindo ao "estímulo condicionado" tão conhecido em psicologia, particularmente na corrente inaugurada por Watson, freqüentador dos trabalhos de Pavlov em Moscou no início da segunda década. Funcionalmente, este signo está ainda próximo do instrumento mas já distante do estímulo natural. Poder-se-ia dizer que, nestas primeiras elaborações do conceito de signo, Vigotski está preocupado em mostrar a continuidade/descontinuidade que existe entre o estímulo natural e o cultural criado pelo homem. Enquanto o primeiro traduz a relação imediata e direta do organismo com o meio, o segundo cria entre estes uma relação indireta e mediada, exatamente como ocorre com o instrumento técnico na relação do homem com a natureza. $\mathrm{Na}$ articulação desses dois tipos de estímulo Vigotski teria encontrado a explicação da gênese do signo que ele procura. Vejamos se esta interpretação se sustenta.

Reportando-se à afirmação de $\mathrm{Pavlov}^{4}$ de que "a atividade mais fundamental e mais genérica dos hemisférios cerebrais é sinalizar com um infinito número de sinais e com formas mutáveis de sinalização", Vigotski conclui que se a sinalização é a base mais geral das condutas animais e humanas, são os sistemas artificiais de sinalização criados pelo homem, particularmente "a grandiosa sinalização da fala", que dominam a atividade sinalizadora do cérebro (cf. Vygotsky 1997, pp. 54-55, e 1989, pp. 59-62). Os sinais a que se refere Pavlov são os estímulos procedentes do exterior que agem diretamente sobre o cérebro (após serem devidamente processados). Trata-se portanto de sinais naturais comuns aos animais e aos homens. Os sinais artificiais a que se refere Vigotski são funcionalmente semelhantes a eles, porém, e aqui está a diferença, são inventados pelo homem. Como os instrumentos técnicos, eles se interpõem entre o sujeito e o objeto da sua ação; mas, diferentemente deles, agem, não sobre as coisas, mas sobre as pessoas, sobre os outros e sobre si mesmos. Podemos portanto dizer que, na lógica da evolução segundo a qual as formas mais complexas decorrem das formas mais simples que as precederam, os sistemas de sinalização natural constituem a origem e o substrato natural dos sistemas de signos. Não podemos esquecer que todo signo pressupõe um elemento que é material, da ordem do sensível (som, imagem, impressão química, térmica etc.), que é justamente o que permite servir de sinal de alguma coisa para alguém (cf. Pino, 1992). Mas, atenção! Embora os sistemas de sinalização sejam um requisito para a explicação da emergência dos sistemas de signos, são es- 
tes e não aqueles que possibilitam as formas humanas de comportamento. E ainda: é a compreensão destes que permite compreender aqueles. Por outro lado, se os diversos modos de sinalização que encontramos no mundo animal podem ser explicados pela adaptação de cada espécie às condições concretas do seu meio, para a adaptação humana é essencial, diz Vigotski, "uma mudança ativa na natureza do homem" (ibidem, p. 55, itálico do autor). Por quê? - caberia perguntar. "Porque [ela] é a base de toda a história humana”, responderia ele. Com efeito, a história humana é a história de uma dupla e simultânea transformação, como diz Marx (1972, p. 63; 1977, p. 136), da natureza e do homem. Uma não ocorre sem a outra. Ora, isto só é possível porque na atividade humana opera uma dupla mediação: a técnica e a semiótica. Se a mediação técnica permite ao homem transformar (dar uma "forma nova") à natureza da qual ele é parte integrante, é a mediação semiótica que lhe permite conferir a essa "forma nova" uma significação. Um belo exemplo disso pode ser tirado da produção artística, atividade que, em princípio, escapa às determinações do modo alienado de produção. Com a ajuda de ferramentas simples, o gênio de Michelangelo vai delineando formas esculturais na pedra sem alterar sua natureza; formas que materializam a visão que o artista tem dos sentimentos que teria Moisés ao ver, segundo o relato bíblico, o povo de Israel adorando o "bezerro de ouro" no momento em que Jeová acaba de selar sua aliança com ele. À medida que as formas esculturais se delineiam na pedra, tornam-se o signo desses sentimentos plasmados nela com tanta força artística que quem olha a escultura do Moisés sente-se envolvido por eles como o fora o próprio artista.

Esse exemplo mostra o que hoje sabemos, graças a Peirce, Vigotski e outros, a respeito do signo. Este tem uma estrutura triádica como mostrado na figura 2:

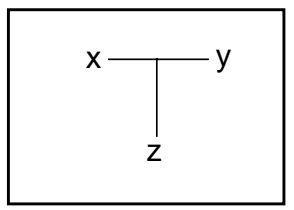

Figura 2: estrutura do signo

onde " $x$ " é uma materialidade (as formas esculturais) que está no lugar de outra coisa "y" que ela representa (o personagem bíblico) sob algum aspecto específico " $z$ " (os sentimentos do personagem bíblico interpretados 
pelo artista). Observe-se que a relação $x$ <> y é função do terceiro elemento " $z$ ", o qual nos permite entender por que $o$ artista escolheu aquelas formas esculturais e não outras, ao mesmo tempo que elas nos informam a respeito de certas características de Moisés, tal como o artista o imaginou. Peirce (1990) chama a este elemento de interpretante, ou seja, aquilo que nos permite saber por que e em que " $x$ " pode ser relacionado com " $y$ ".

Diferentemente do simples sinal, o signo tem a propriedade de ser reversível, ou seja, a de significar tanto para quem o recebe quanto para quem o emite. A escultura do Moisés não só significa algo para quem a contempla mas também para Michelangelo, que a produziu. $O$ artista pode "ver-se" na sua obra. A medida em que a produz, torna-se o "outro" que olha e interpreta. O signo opera no campo da consciência, no qual ser autor e espectador constituem atributos de uma mesma pessoa. É por isso que a palavra dirigida ao outro produz efeito também naquele que a pronuncia. No mundo dos sinais não há reversibilidade, pois eles operam em um campo em que ainda não há consciência.

No campo da linguagem, Bakhtin identifica o sinal com a forma lingüística e o signo com a sua significação num dado contexto enunciativo. Enquanto o sinal é simplesmente identificado, o signo tem de ser decodificado ou interpretado. O sinal faz parte do mundo dos objetos, constituindo uma entidade de conteúdo invariável. O signo, ao contrário, faz parte do mundo dos sujeitos, constituindo uma entidade móbil e variável em função do contexto enunciativo. "A palavra," diz Bakhtin, "está sempre carregada de um conteúdo ou de um sentido ideológico ou vivencial" (1988, p. 95).

Nesse sentido, Vigotski pode dizer, com toda razão, que "o problema da conduta verbalizada é o problema central em toda história do desenvolvimento cultural da criança" (1989, p. 56). Com efeito, o evento determinante da história humana, da qual faz parte a história da criança, é a criação dos mediadores semióticos que operam nas relações dos homens com o mundo físico e social. Instalando-se nos espaços dos sistemas de sinalização natural, estes mediadores os tornam espaços representacionais, de modo que emerge um mundo novo, o mundo simbólico ou da significação.

É a significação que confere ao social sua condição humana, fazendo da sociabilidade animal - expressão de uma organização natural da convivência de indivíduos de uma mesma espécie - uma sociabilidade humana - expressão da maneira como os membros da espécie humana organizam a sua convivência. Isto quer dizer que a convivência humana é regida por leis históricas, e não por mecanismos naturais ou 
biológicos. É aqui que entra o sentido estrito de história a que se refere Vigotski na nota introdutória do "Manuscrito", história da produção pelos homens das suas condições sociais de existência.

\section{O social e as funções superiores}

As funções superiores constituem o terceiro tipo de objetos a que Vigotski atribui caráter social, não só porque elas não emergem das funções biológicas, mas porque sua natureza é social. "Elas são", diz Vigotski, "relações internalizadas de uma ordem social, transferidas à personalidade individual e base da estrutura social da personalidade" (1989, p. 58). Tudo nelas é social: sua composição, sua estrutura genética e seu modo de funcionar. De tal modo que, mesmo sendo transformadas em processos mentais, permaneçam quase sociais, como ele diz (1997, p. 106).

Mas o que quer dizer com isso? Por acaso o "quase" é um redutor do seu caráter social? Um quantum que Ihes faltaria para serem sociais? Não creio que essa seja uma interpretação correta, pois se thes faltasse algo ainda não seriam sociais, caindo por terra a argumentação. Vigotski estabelece uma relação de equivalência, não de identidade, entre as relações sociais enquanto estruturas da sociedade e as relações sociais enquanto estrutura social da personalidade. É uma diferença não de natureza mas de modo de operar segundo se trate de relações da pessoa no mundo público, interpessoal, ou no mundo privado, pessoal. Esta é uma questão fundamental na concepção de desenvolvimento cultural proposta por Vigotski, à qual voltarei mais adiante.

Antes disso, encerrando a questão do significado que o termo social tem para Vigotski, podemos tirar algumas conclusões. Primeiro, o social é uma categoria geral que se aplica a um conjunto de fenômenos que, tanto no mundo animal quanto no mundo humano, envolvem diferentes formas de organização dos indivíduos. Segundo, tanto no mundo animal quanto no mundo humano, o social é um "valor agregado" ao biológico, qualquer que seja a maneira como ele emerge. Isso quer dizer que, se o biológico constitui o substrato de toda forma de sociabilidade, não constitui porém causa suficiente para a sua emergência, relacionada às diferentes formas de adaptação de determinadas espécies de organismos às condições de existência nos seus respectivos meios ecológicos - formas de adaptação que evoluem em função das mudanças que ocorrem nessas condições de existência. A pergunta que ainda aguarda uma resposta é: como e em que medida as experiências adaptativas bem sucedidas 
podem se tornar padrões inatos de conduta? Terceiro, o social ao qual Vigotski se refere especificamente é o social humano, cuja emergência, com maior razão que a das formas animais de sociabilidade, tem de ser explicada por princípios outros, e não os meramente naturais ou biológicos. As formas humanas de organização social, em que a sociabilidade natural se concretiza, são obra do homem e, como tal, obedecem a leis históricas que determinam as condições concretas de sua produção. É o caráter histórico dessa produção que define o social humano.

\section{Relações sociais e constituição do homem}

A introdução das relações sociais como definidoras da natureza das funções mentais superiores, ou seja, da natureza humana do homem, constitui uma "subversão" do pensamento psicológico tradicional. Vigotski desloca definitivamente o foco da análise psicológica do campo biológico para o campo da cultura, ao mesmo tempo que abre o caminho para uma discussão do que constitui a essência do social enquanto produção humana. A questão das relações sociais torna-se o eixo, nem sempre claramente explicitado, dos seus trabalhos dedicados à análise do desenvolvimento humano, ao qual convêm mais o qualificativo de cultural que lhe dá este autor do que o de psicológico que Ihe dá a psicologia tradicional.

Das diferentes formulações da natureza das funções superiores que encontramos nos trabalhos de Vigotski, a mais contundente é, sem dúvida alguma, aquela em que, recorrendo a uma das "Teses sobre Feuerbach" de Marx e Engels (1982), especificamente a sexta, afirma: "a natureza psicológica do homem é a totalidade das relações sociais transferidas à esfera interna e tornadas funções da personalidade e formas da sua estrutura" (1989, p. 59; 1997, p. 106). O que talvez possa parecer ao leitor desatento uma frase de efeito retórico, na realidade traduz uma concepção - inédita em psicologia - da natureza psicológica do homem. Extremamente complexa, o próprio Vigotski não esclareceu completamente essa questão, embora tenha nos deixado elementos para poder compreendê-la.

Ao assumir essa tese, Vigotski desautoriza uma interpretação do sentido de relações sociais que não seja aquele que elas têm no pensamento marxista, qualquer que seja a idéia do leitor acerca deste pen- 
samento. Sabe-se que as "Teses sobre Feuerbach" sintetizam a crítica de Marx e Engels a este autor, ele mesmo crítico do idealismo de Hegel, seu mestre. Hegel é criticado por ter colocado como base de sua filosofia uma concepção abstrata do ser, tomado como um Absoluto (sinônimo de Idéia e Espírito) e não como uma realidade material da qual o homem é o produto, realidade que pode ser captada por uma simples intuição empírica. Na sua atitude crítica em relação a Hegel, Feuerbach propõe uma filosofia que tenha como ponto de partida a realidade material, empírica e sensível do homem para poder chegar sua essência. Feuerbach identifica tal essência com a abstração que ele denomina de homem genérico: síntese de todas as qualidades que, não existindo de forma eminente em nenhum indivíduo em particular, são projetadas na idéia de Deus ${ }^{5}$.

O que Marx e Engels criticam, especificamente, é o materialismo sensualista de Feuerbach, crítica sintetizada na afirmação que constitui a idéia principal da sexta tese: "Mas a essência humana não é uma abstração inerente ao indivíduo singular. Na sua realidade é o conjunto das relações sociais"6 (1982, p. 52). Feuerbach é criticado por ter feito do homem um simples produto das circunstâncias materiais, esquecendo-se que são os homens que transformam essas circunstâncias. $O$ argumento é claro: a maneira como os homens produzem/reproduzem, pelo trabalho social, as suas condições de existência, físicas e sociais, representa o seu modo de vida próprio, o qual reflete mais precisamente o que eles são. Existe uma estreita interdependência entre o modo de ser dos homens (sua essência), seus modos de produção (condições de produção) e o tipo de relações sociais que deles decorrem (Marx \& Engels, 1982, pp. 70-71). Como lembra J. Milhau, no seu extenso prefácio à Ideologia alemã (1982, pp. 19-20), as "Teses" criticam o caráter intuitivo, estático, passivo e a-histórico do materialismo de Feuerbach. Rejeitam também sua concepção de homem baseada na idéia abstrata induzida pela constatação geral da existência de indivíduos, mas ignorando as relações sociais históricas que condicionam e transformam sua realidade concreta. "De fato", diz Milhau, "contra toda aparência, a essência do homem não é identificável com o ser de um indivíduo natural e isolado, robinsonada que só existe no espírito do ideólogo." A maneira como os homens se relacionam com a natureza e entre si depende dos modos de produção e das condições de acesso deles aos bens produzidos. A idéia de Marx, de que "não é a consciência que determina a vida, mas a vida que determina a consciência" (1982, p. 78), aplica-se, segundo Vigotski, a todas as funções psicológicas (pensamento, linguagem, percepção, memória etc.). O que significa que, se por vida entendemos as novas 
condições de existência criadas pelo homem e não as existentes na natureza, estas funções não são o produto destas mas daquelas. À concepção naturalista do desenvolvimento humano, amplamente difundida nos meios psicológicos, Vigotski contrapõe a concepção dialética - o que o leva a procurar outros métodos que sejam coerentes com esta concepção do desenvolvimento:

O elemento-chave do nosso método [...] decorre diretamente do contraste estabelecido por Engels entre as abordagens naturalista e dialética para a compreensão da história humana. Segundo Engels, o naturalismo na análise histórica manifesta-se pela suposição de que somente a natureza afeta os seres humanos e de que somente as condições naturais são os determinantes do desenvolvimento histórico. A abordagem dialética, admitindo a influência da natureza sobre o homem, afirma que o homem, por sua vez, age sobre a natureza e cria, através das mudanças produzidas nela, novas condições naturais para a sua existência. Essa posição representa o elemento-chave de nossa abordagem do estudo e da interpretação das funções psicológicas superiores. (1984, pp. 69-70)

Na perspectiva em que se situa Vigotski, as relações sociais são determinadas pelo modo de produção que caracteriza uma determinada formação social. Isso nada tem a ver com qualquer tipo de determinismo mecanicista que ele mesmo critica, uma vez que os modos de produção não são dados pela natureza mas determinados pelos homens (por aqueles que detêm o poder na sociedade) em função de interesses específicos. Seria ingenuidade portanto pensar que Vigotski fala de relações sociais como algo natural e ideologicamente neutro. Muito pelo contrário. E um texto publicado em 1930, consagrado à discussão da formação socialista do homem, ele é categórico:

Da mesma maneira que a vida da sociedade não representa um todo único e uniforme, e a sociedade é subdividida em diferentes classes, assim, durante um dado período histórico, a composição das personalidades humanas não pode ser vista como representando algo homogêneo e uniforme, e a psicologia deve levar em conta o fato fundamental que a tese geral que foi formulada recentemente só pode ter uma conclusão direta, confirmar o caráter de 
classe, a natureza de classe e as diferenças de classe que são responsáveis pela formação dos tipos humanos. As várias contradições internas que foram encontradas em diferentes sistemas sociais encontram sua expressão, ao mesmo tempo, no tipo de personalidade e na estrutura da psicologia humana neste período histórico. (1994, p. 176)

Embora Vigotski não discuta especificamente esta questão, podemos pensar que as relações sociais constituem um complexo sistema de posições sociais e de papéis associados a essas posições que define como os atores sociais se situam uns em relação aos outros dentro de uma determinada sociedade e quais são as expectativas de conduta ligadas a essas posições. Por outra parte, dado que as relações sociais são determinadas pelo modo de produção da sociedade, as posições sociais e os papéis a elas associados traduzem a maneira como as forças produtivas se configuram nessa sociedade. É importante relembrar que a tese das relações sociais, tal como é proposta por Marx e Engels e formulada por Vigotski, constitui uma problemática que envolve dois planos diferentes mas interligados: o plano estrutural da organização social, com suas dimensões políticas e econômicas, e o das relações pessoais entre indivíduos concretos. Embora teoricamente diferentes, estes dois planos têm que ser regidos pelas mesmas leis históricas, caso contrário as estruturas sociais não passariam de meras abstrações sem fundamento na realidade. A relação entre esses dois planos constitui, sem dúvida, um complexo problema teórico para as ciências sociais e psicológicas, fonte permanente de soluções incompletas. É o problema da articulação das decisões pessoais e os determinantes históricos decorrentes dos modos de organização social das sociedades. Sem decisões pessoais a organização social é impensável; mas sem organização social é impossível falar em decisões pessoais sem retornar à pré-história do contrato social, como o mostram, entre outros, os trabalhos de Locke, Hobbes e Rousseau.

Penso que na leitura dos trabalhos de Vigotski seria um grande equívoco separar estes dois planos, como se as relações entre as pessoas nada tivessem a ver com as estruturas sociais da sociedade. Nada mais equivocado, após ele ter colocado como princípio geral da constituição cultural do homem a sexta "tese sobre Feuerbach". Se Vigotski concentra suas análises nas relações sociais concretas entre as pessoas é porque ele está preocupado em mostrar como elas se tornam "fun- 
ções do indivíduo e formas da sua estrutura" (1989, p. 64). Mas a lógica da sua análise pressupõe que estas relações se situam no quadro das relações estruturais da sociedade determinadas pelo modo de produção. Independente do que o leitor pense a respeito da análise de Marx e Engels, fazer uma leitura diferente de Vigotski constitui, certamente, um reducionismo do pensamento do autor.

Assumir a tese de que as funções superiores são relações sociais internalizadas implica em assumir também o ônus da prova, o que não é tarefa tão simples assim, principalmente por não ter sido objeto de uma análise mais sistemática por parte de Vigotski. Duas razões tornam particularmente difícil esta tarefa. A primeira é que toda relação social envolve o outro, o qual, para manter a coerência interna da tese, deve ser também objeto de internalização. A segunda é que o mecanismo pelo qual as relações sociais são reconstituídas no plano pessoal não é evidente em si mesmo, mas tem de ser explicado.

Quanto ao envolvimento do outro nas relações sociais, a posição de Vigotski é muito clara. Ele afirma repetidas vezes o papel do outro na constituição cultural do homem. "Nós nos tornamos nós mesmos através dos outros", diz ele repetidas vezes, vendo neste princípio a essência do processo de desenvolvimento cultural na sua forma puramente lógica (1989, p. 56). Não se trata de fazer do outro um simples mediador instrumental, particularmente no caso da criança cujo desenvolvimento estaria irremediavelmente comprometido sem a presença prestimosa e a ajuda constante do outro. A mediação do outro tem um sentido muito mais profundo, fazendo dele a condição desse desenvolvimento. Segundo Vigotski, o desenvolvimento cultural passa por três estágios ou momentos, lembrando a análise hegeliana ${ }^{7}$ : o desenvolvimento em si, para os outros e para si. O primeiro momento é constituído pelo "dado" em si, realidade natural ou biológica da criança enquanto algo que está dado. É o momento teórico que precede à emergência do estado de cultura. O segundo momento é aquele em que o "dado" em si adquire significação para os outros (para os homens, em sentido de coletividade ou gênero, como diz Marx). É o momento histórico da emergência do estado de cultura; momento de distanciamento do homem da realidade em si, a qual se desdobra nele na forma de representação, testemunhando a presença da consciência. Enfim, o terceiro momento é aquele em que a significação que os outros atribuem ao "dado" natural se torna significativo para si, ou seja, para o indivíduo singular. É o momento da constituição cultural do indivíduo quando, através desse outro, ele internaliza a significação do mundo transformado pela ati- 
vidade produtiva, o que chamamos de mundo cultural. Portanto, o desenvolvimento cultural é o processo pelo qual o mundo adquire significação para o indivíduo, tornando-se um ser cultural. Fica claro que a significação é a mediadora universal nesse processo e que o portador dessa significação é o outro, lugar simbólico da humanidade histórica.

A crítica que Marx dirige à dialética de Hegel é que este faz desses momentos um movimento interno à "consciência de si", do qual a realidade concreta é o resultado. Ora, diz Marx, é o contrário que ocorre: não é a consciência que determina as condições materiais, mas estas que determinam a consciência, como vimos anteriormente. Dessa forma, o "para o outro" da "consciência de si" de Hegel torna-se em Vigotski, na linha de Marx, o para os outros, expressão do movimento da história dos homens no qual cada indivíduo deve inserir-se para construir sua própria história. Um exemplo concreto da dialética desse movimento na constituição cultural da criança é dado por Vigotski ao analisar a "história do ato de apontar"(1997, pp. 104-105). Trata-se de um exemplo aparentemente simples mas que, como ele mesmo diz, é paradigmático do desenvolvimento cultural, pois mostra o caminho da inserção da criança na história cultural dos homens. Em síntese, esse exemplo nos mostra que pela significação que o outro atribui às expressões da vida natural ou biológica da criança (como o "movimento de apontar") é que estas adquirem significação para ela. A criança, diz Vigotski, "é a última em reconhecer seu gesto", ou seja, só capta a significação do seu ato através do outro.

A problemática colocada pelo papel das relações sociais na constituição cultural do homem nos conduz à outra questão: a do mecanismo que possibilita a conversão dessas relações em funções do indivíduo e em formas da sua estrutura. Esse mecanismo é a significação veiculada/produzida pela "palavra do outro". Como mostrei em outro lugar (Pino, 1992), o objeto a ser internalizado é a significação das coisas, não as coisas em si mesmas. Portanto o que é internalizado das relações sociais não são as relações materiais mas a significação que elas têm para as pessoas. Significação que emerge na própria relação. Dizer que o que é internalizado é a significação dessas relações equivale a dizer que o que é internalizado é a significação que o outro da relação tem para o eu; o que, no movimento dialético da relação, dá ao eu as coordenadas para saber quem é ele, que posição social ocupa e o que se espera dele. Dito de outra forma, é pelo outro que o eu se constitui em um ser social com sua subjetividade - o que é coerente com o modelo dos três estágios de que acabo de falar. Se o que internalizamos das relações sociais é a significação que o outro da relação tem para o eu, esta signifi- 
cação vem através desse mesmo outro. O outro passa a ser assim, ao mesmo tempo, objeto e agente do processo de internalização, ou seja, o que é internalizado e o mediador que possibilita a internalização. Esse pode ser o sentido de outra das afirmações de Vigotski: "eu me relaciono comigo mesmo como as pessoas se relacionam comigo" (1989, p. 57).

Numa interpretação simples das palavras de Vigotski, poderia se pensar que o que ocorre no plano pessoal é uma simples imitação do que ocorre no plano social da relação. Mas numa interpretação mais cuidadosa pode-se dizer que, ao interiorizar a significação do outro da relação (e não podemos esquecer que cada pessoa faz parte de uma malha de relações diferentes), o indivíduo está dando entrada na sua esfera íntima a esse outro, o socius de que fala Wallon (1975), ao qual se refere em termos poéticos: "fantasma dos outros que cada um traz em si"; "esse estranho essencial"; "parceiro perpétuo do eu".

O socius ou o outro é um parceiro perpétuo do eu na vida psíquica. É normalmente reduzido, inaparente, contido e como que negado pela vontade de dominação e de integridade completa que acompanha o eu. No entanto, toda a deliberação, toda a indecisão é um diálogo às vezes mais ou menos explícito entre o eu e um objectante. Nos momentos de incerteza, nas circunstâncias graves que empenham de maneira urgente a responsabilidade, o diálogo pode ser já não íntimo, mas falado [...] No entanto, o sentimento de dualidade pode ser mais vivo. O demônio de Sócrates, essa intervenção que, para Sócrates, tinha o caráter de uma intervenção exógena e que se produzia nas circunstâncias importantes para Ihe desaconselhar um ato sobre o qual ele hesitava, é um caso deste gênero [...] (Wallon, 1975, pp. 159-160).

Caberia aplicar aqui também a idéia do Homo Duplex a que se refere freqüentemente Vigotski. Uma vez que toda relação social é relação de um eu e um outro, sua internalização implica na conversão de dois numa unidade onde o outro permanece sempre presente como um "não eu", um estranho, mas "um estranho essencial", como afirma Wallon. Além disso, se as relações reais entre pessoas constituem geneticamente o substrato das funções psicológicas, como diz Vigotski, então é fácil entender por que a subjetividade humana adquire a forma de drama real (1989, p. 59).

O termo conversão, usado várias vezes por Vigotski ao referir-se à transformação das relações sociais em funções psicológicas, pode nos aju- 
dar a esclarecer melhor a maneira como ocorre esse processo de transformação ou internalização, embora o autor não nos forneça elementos para isso. Dos vários sentidos em que o termo "conversão" é usado na linguagem comum e erudita, destacam-se dois que podem nos dar uma pista para esclarecer o que buscamos. Refiro-me, de um lado, ao sentido que o termo tem em física: mudança de um corpo de um estado a outro (por exemplo, a conversão de um corpo do estado sólido ao estado líquido). De outro lado, refiro-me ao uso comum desse termo para designar a mudança por que podem passar as pessoas no campo das idéias (políticas, sociais ou religiosas) num determinado momento da sua vida. Em ambos os casos, a mudança supõe a emergência de algo novo e diferente a partir de algo que, na sua essência, continua o mesmo (a água não deixa de ser água por passar do estado líquido ao estado gasoso ou sólido e a pessoa não deixa de ser ela por mudar de religião ou de ideologia, mas, em ambos os casos, nem a água nem a pessoa são as mesmas). A conversão implica uma diferença de uma semelhança. No campo das mudanças psicológicas, isto nos leva, de um lado, à idéia de réplica, de que fala Wallon (1942) ao analisar o fenômeno da imitação de modelos, e, do outro, à idéia de mudança de sentido ou re-significação, como ocorre no processo de conversão ideológica ou religiosa. Entendida assim e na lógica do pensamento de Vigotski, a internalização das relações sociais consistiria na "conversão" das relações físicas entre pessoas numa réplica delas na esfera privada da pessoa. O que implica, ao mesmo tempo, mudança de estado - de mundo público para mundo privado - e mudança de sentido - significação que as relações sociais têm para o indivíduo. A conversão não é um processo automático; ao contrário, ela pressupõe a atividade do sujeito, o que deveria acalmar o temor de alguns, como o diz J. Valsiner (1988, 1994), de destituição do estatuto do sujeito sob um suposto determinismo do meio social-cultural.

A conversão supõe uma mudança de um estado ou condição "A" para um estado ou condição "B", onde algo essencial permanece constante, tornando a conversão um processo reversível. Na conversão das relações sociais em relações intrapessoais, o elemento que permanece constante é a significação. Mas a significação social das relações é convertida em significação pessoal ("quase social") dessas relações. Estas adquirem o sentido que Ihes dá o indivíduo. Por exemplo, a significação social da relação "pai <> filho", instituída pela sociedade, converte-se na significação que tal pai tem para tal filho e vice-versa. Significações diferentes e que, por isso mesmo, são a fonte de crises e conflitos pessoais, como o mostra a experiência da vida cotidiana. A função mediadora da significa- 
ção possibilita a reversibilidade do processo: o que é social se converte em pessoal e o que é pessoal se converte em social. Ela garante a coerência entre os mundos público e privado da pessoa. A idéia da reversibilidade aparece claramente na função do terceiro elemento que compõe o modelo de signo proposto por Peirce (1990), que ele denomina de interpretante justamente porque a significação do signo tem de ser interpretada e, para tanto, este tem que ser interpretável. É o interpretante que permite que haja conversão da significação do signo em significação do seu intérprete. Como o salienta este autor, ao ser interpretado, o signo dá origem na mente do intérprete a outro signo que, ao ser interpretado, gera outro interpretante que gera outro signo e assim indefinidamente. Essa cadeia de significação constitui o que entendemos por semiose: um processo de geração ou conversão de uma significação em outra, o que permite a constante produção de sentido nos processos dialógicos.

\section{Relações sociais e funções superiores}

Ao retomar, num texto posterior ao "Manuscrito", a questão da natureza social das funções psicológicas, Vigotski lembra que, "na sua esfera privada, o homem retém as funções da socialização" (1997, p. 106), ou da interação social, como aparece na tradução de Wertsch ${ }^{8}$. Isto pode abrir uma clareira na penumbra da floresta conceptual.

Antes de discutir em que esta expressão pode nos ajudar a explicar a maneira como ocorre a transformação das relações sociais em funções superiores, retomo aqui algumas das idéias já discutidas em outro lugar (Pino 1999, pp. 41-44), a respeito do termo função do qual Vigotski faz um uso constante nos seus trabalhos. Embora não saibamos qual foi a razão da escolha deste termo nem o sentido exato que ele lhe atribui, é certo que não tem nada a ver com o sentido que lhe é dado pelas teorias funcionalistas, em psicologia e em outras áreas do conhecimento. Como pode se verificar no texto onde ele trata especificamente da gênese das funções mentais superiores (Vygotsky 1997), o autor utiliza, indistintamente, diferentes termos para referir-se a mesma coisa: "formas superiores de conduta", "formas mentais", "processos mentais superiores" e "funções mentais superiores". De qualquer maneira, ao conceber o psiquismo como um conjunto de funções e estas como sendo de natureza cultural, não biológica, Vigotski se distancia tanto das teorias funcionalistas e estruturalistas quanto das concepções biologizantes e mecanicistas. 
Se o caráter vago do termo "função", tal como é usado por Vigotski, coloca certas dificuldades conceituais, por outro lado ajuda a conceber o psiquismo como algo dinâmico, que está sempre se (re)fazendo e em perpétuo movimento. Algo que nos faz pensar na criação ininterrupta do velho no novo, do significado dado na flutuação do sentido. Entendido assim, o termo função permite ver as "funções mentais" de que fala Vigotski como um acontecer permanente. Conservando um certo grau de consistência e de continuidade, apresentam-se sempre sob o signo do novo. É claro que a capacidade de pensar, de falar, de registrar em memória etc. são funções permanentes da pessoa, mas sujeitas às leis históricas das condições da sua produção: produção da fala, das idéias, das lembranças etc. Essas funções são portanto função dessas condições de produção, as quais não permanecem sempre necessariamente as mesmas. O que nós pensamos, o que nós dizemos, o que nós rememoramos depende das condições concretas em que isso ocorre. Se isso não impede que idéias, discursos ou lembranças possam ser reproduzidas no tempo com uma certa persistência, elas têm de ser cada vez (re)pensadas, (re)ditas ou (re)memoradas. Em cada instante algo novo está prestes a emergir. Neste conceito de função, fundem-se, sem se confundirem, o ato de funcionar e o funcionar de uma certa maneira; o ato de produzir e o produto desse ato. Assim, as funções de pensar, de falar, de rememorar concretizam no ato de pensar, de falar ou de rememorar alguma coisa cuja significação pode não ser a mesma em cada instante. $\mathrm{Na}$ sua opacidade e ambigüidade, o termo função permite romper com uma visão tradicional e nada esclarecedora de psiquismo, concebido como um conjunto de realidades ontológicas, estáticas e a-históricas, as "faculdades da alma" dos antigos (a inteligência, a afetividade, a memória etc.), assimiladas às funções biológicas ligadas a determinados órgãos do corpo. O termo função, ao contrário, permite articular o que é conquista da espécie, que constitui as suas características e, por conseguinte, é algo acrescido à evolução biológica, com o que deve ser conquista de cada indivíduo singular. Articular o que está dado na natureza da espécie Homo Sapiens (possibilidade de pensar, falar, sentir, rememorar etc.) com o que não está e tem de ser adquirido por cada membro dessa espécie (tornar-se um ser que pensa, fala, sente, rememora etc. alguma coisa concreta). Isso quer dizer que o que pensamos, falamos, sentimos, lembramos etc. não é algo que já está pronto, à disposição do indivíduo para o seu uso. Enquanto objetos semióticos, as idéias, as palavras, os sentimentos ou as lembranças têm de ser produzidos. E, mesmo depois de terem sido produzidos, quando já passaram a fazer parte do repertório de experiências registradas em memória, têm de ser "dados à luz" por um novo ato de pensar, falar, sentir, rememorar etc. 
No texto a que me refiro acima (Pino,1999), lembro que dentre os vários sentidos em que o termo função é utilizado tanto pela literatura especializada quanto pelo uso comum, há dois especialmente úteis para fazer algumas conjeturas acerca do sentido que tal termo pode assumir no contexto dos trabalhos de Vigotski, uma vez que não é explicitado pelo autor. Um é o sentido que tem no campo sociológico, em que o termo significa os papéis associados a determinadas posições sociais. $O$ outro é o sentido dado no campo matemático, de correspondência entre os elementos de dois diferentes conjuntos. Embora distintos, ambos podem ser combinados, uma vez que todo papel é função de uma posição social que, por sua vez, é função de outra posição e de outros papéis. Por exemplo, na relação "mestre-servo", os papéis associados à posição de "mestre" são função dos papéis associados à posição de "servo" e vice-versa. Só há "mestre" se há um "servo" que lhe presta serventia e só há "servo" se há um "mestre" que lhe exerça senhorio. Os papéis associados a cada uma dessas posições, ao mesmo tempo que se contrapõem e se negam em reciprocidade, constituem-se mutuamente.

Retornando à afirmação de Vigotski de que o que os seres humanos retêm na sua esfera privada das relações sociais são "as funções da socialização", ou, como aparece na tradução de Wertsch, "as funções da interação", o que o autor está dizendo é que o que é internalizado das relações sociais são as "funções dessas relações", as quais se tornam "funções superiores do indivíduo". Embora as duas expressões, resultantes de traduções diferentes do original russo, possam ser consideradas sinônimas, a segunda parece-me mais específica para analisar o conceito do termo "função". Mesmo não sabendo qual foi a razão que levou o autor a utilizar essa expressão nem o sentido exato que tem para ele, creio que ela pode nos fornecer uma pista para analisar o significado do termo "função" na concepção que Vigotski tem das "funções superiores", que, como sabemos, são "relações sociais internalizadas".

Se por "interação social" entendermos a forma concreta que as relações sociais das pessoas tomam, ou seja, as ações e reações dos envolvidos numa relação, a expressão "funções da interação social" pode ser entendida, seja como o princípio que rege essas ações e reações, seja como o efeito que as ações/reações de cada membro da relação produz nas ações/reações do outro. Em ambos os casos, o termo "função" tem o duplo sentido que lhe atribuí acima: o sociológico e o matemático. De um lado, a interação de pessoas em relação é função da posição que cada uma ocupa na relação. Do outro, as funções (ou seja, as ações/reações) 
associadas a uma posição, são função das funções associadas à outra. Assim, por exemplo, a relação pai <> filho é função do princípio que rege essa relação (o de paternidade/filiação), ao mesmo tempo que as funções associadas à posição de filho são função das funções associadas à posição de pai e vice-versa. Isso tanto é verdade no plano legal, onde as posições sociais e suas respectivas funções (papéis, ações ou comportamentos) estão previamente definidas, refletindo as estruturas de relação da sociedade, quanto no plano pessoal, em que elas têm de ser reconhecidas por cada um dos integrantes da relação. Neste caso, a posição de pai é função do reconhecimento do pai por parte do filho e a de filho é função do reconhecimento do filho por parte do pai, pois ninguém é pai sem o reconhecimento do filho, nem filho sem o reconhecimento do pai. Daí a possibilidade de existência de conflitos entre os dois planos, o legal e o subjetivo (o pai continua legalmente sendo pai mesmo se o filho não o reconhece como tal e vice-versa). O princípio da relação permanece, porém, o mesmo nas duas instâncias. Nessa linha de raciocínio, podemos então dizer que as funções psicológicas são a conversão, na esfera privada, da significação que as posições sociais têm na esfera pública. O que nos conduz a afirmar que as funções psicológicas constituem a projeção na esfera privada (plano da pessoa ou da subjetividade) do drama das relações sociais em que cada um está inserido. Ou, em outros termos, as funções psicológicas são função da significação que as múltiplas relações sociais tem para cada um dos envolvidos nelas, com todas as contradições e conflitos que elas envolvem em determinadas condições sociais. A esse respeito, é interessante a referência de Vigotski a Janet (1989, p. 61) a respeito do que este diz sobre as funções da palavra: primeiro, aparecem desempenhadas por indivíduos diferentes (esfera pública), depois, por uma única e mesma pessoa (esfera privada). Uma idéia à qual Vigotski retorna repetidas vezes: o que, no plano social, é feito por indivíduos diferentes, no plano pessoal é feito pelo mesmo indivíduo. É a idéia do Homo Duplex à qual me referi anteriormente e que poderia ser interpretada como o fato de o mesmo indivíduo desempenhar a função de "eu" e de "outro" da relação. Uma vez que o indivíduo está envolvido numa ampla rede de relações diferentes, pode-se dizer que ele é uma unidade feita de múltiplas relações em que ocupa múltiplas posições de sujeito de relação. Isto levanta a questão que Vigotski se coloca no "Manuscrito" e que figura como epígrafe deste trabalho: "Que é o homem? Para Hegel é um sujeito lógico. Para Pavlov, é um soma, um organismo. Para nós, o homem é uma pessoa social = um agregado de relações sociais incorporadas num indivíduo" (1989, p. 66, itálico no texto). 
Vigotski raramente utiliza o termo "sujeito" e, quando o faz, não é no sentido que ele tem na tradição psicológica. Por isso, a introdução da idéia de "pessoa social" como definidora do homem poderia ser entendida como uma categoria equivalente à de sujeito. Mas a coisa não é tão simples. Com efeito, a idéia de "pessoa social", no contexto em que ela aparece, é o equivalente de "agregado de relações sociais incorporadas num indivíduo", o que fala mais de multiplicidade que de unidade, como é entendida a idéia de sujeito psicológico. Como vimos anteriormente, o "sujeito da relação" não é o mesmo em todas as relações sociais. A posição que ele ocupa em cada uma delas varia em função do tipo de relação. Assim, não é a mesma coisa alguém ocupar a posição de "magistrado" numa relação em que o réu é o próprio filho do que ocupar a posição de "pai" na relação com esse filho. Mas, se as posições do "sujeito da relação" variam em função do outro sujeito dessa relação, a "pessoa social" envolvida em todas as relações sociais permanece a mesma. O que quer dizer que a idéia de "pessoa social" envolve a idéia, ao mesmo tempo, de unidade e de multiplicidade, o que coloca em xeque o conceito tradicional de sujeito psicológico.

$\mathrm{Na}$ seqüência de suas reflexões, Vigotski levanta indiretamente a questão da relação entre a "pessoa" e as "funções superiores" da pessoa, as quais, como já sabemos, são relações sociais internalizadas. A conclusão é que embora as leis que regem as funções superiores sejam as mesmas, a maneira como elas funcionam ou operam varia de pessoa para pessoa. Isso quer dizer que se pensar, falar, sentir, rememorar, sonhar etc. são processos regulados pelas mesmas leis históricas, o que cada pessoa pensa, fala, sente, rememora, sonha etc. é função da sua história social. O que, associado ao que foi dito a respeito das "funções da interação social", nos conduz a afirmar que o que cada pessoa pensa, fala, sente, rememora, sonha etc. é função do que o outro das múltiplas relações sociais em que ela está envolvida pensa, fala, sente, rememora, sonha etc. Insistindo em que não são as idéias, as palavras, os sentimentos, as lembranças, sonhos etc. do outro que são internalizados mas a significação que eles têm para o eu, pois a conversão do social em pessoal é um processo semiótico. De outra forma, seria difícil entender como as relações sociais podem se converter em funções da pessoa.

Vigotski introduz a questão da pessoa no "Manuscrito" quando discute o papel do signo nas conexões cerebrais, assunto tratado anteriormente. Ele procura mostrar que com o signo ocorre um deslocamento da fonte do mecanismo regulador das funções nervosas: das relações inter- 
nas das funções e estratos do cérebro para as relações sociais. Isso o leva a discutir a "metáfora do telefone", da qual Pavlov se serviu para mostrar que, além da "rede telefônica", a complexa rede de conexões nervosas, existe no cérebro um centro regulador, o "operador dessa rede". Vigotski aproveita essa metáfora para mostrar duas coisas: primeiro, que o peculiar no caso do homem é que ele é, ao mesmo tempo, a rede e o operador dessa rede. Segundo, que se a rede é de natureza neurológica, não o é o operador da rede, o qual se constitui a partir do social. Pode-se então concluir que o operador da rede é também a própria rede.

Mas, quem é esse operador? Vigotski responde: "a personalidade social da pessoa". À primeira vista, a resposta soa um tanto estranha. Além de introduzir uma categoria ausente nos seus escritos, ou seja, a pessoa, destaca nela uma dimensão social - a personalidade, que ele define como "a totalidade das relações sociais" - o que permite pressupor que existe algo não social na pessoa. Isso pode ser esclarecido se considerarmos que por "pessoa" ele entende: "um membro de um grupo social específico"; "uma unidade social definida", "um ser em si, para os outros, para si mesmo' (1989, p. 64, itálico no texto). Nessas três formulações, diferentes mas complementares, Vigotski está afirmando que entende por pessoa um indivíduo social, real e concreto, cuja singularidade se constitui enquanto membro de um grupo social-cultural específico. Um indivíduo, pois, que é um ser em si, uma natureza biológica portanto, que tem significação para os outros, e que, através deles, adquire significação para si mesmo. Como foi visto antes, Vigotski retoma aqui a fórmula hegeliana da dialética da "consciência de si", na sua reformulação por Marx e Engels. Com a categoria de pessoa, Vigotski introduz na sua teoria a unidade que articula a diversidade de funções, ao mesmo tempo que recoloca a psicologia no campo da realidade concreta. Idéia que Puzirei parece ter querido destacar ao dar o título de "Concrete Human Psychology" à tradução inglesa que ele fez do "Manuscrito".

Servindo-se do exemplo do sonho, Vigotski tenta mostrar que a pessoa é, ao mesmo tempo, sujeito e objeto. No seu pensamento mágico, Kaffir pode dizer -"eu sonharei isso". "Nele, diz o autor, dormir adquiriu a função reguladora pela significância dos sonhos [...] o que ele vê nos seus sonhos, ele o executará". Esta é a reação de uma pessoa, e não uma reação primitiva (natural). A relação do sonho com uma ação futura equivale, genética e funcionalmente, a uma função social (o que o sonhador vai fazer num quadro social). Portanto, diz Vigotski, "a função social se agrega à pessoa"10. Diferentemente de Kaffir, afirma Vigotski, 
nós diríamos "eu tive um sonho". No primeiro caso, o sujeito sonha. No segundo, o sujeito se vê sonhando. Vigotski conclui: "em toda função existe um eu e um mim" (1989, p. 66). O tempo ativo do "eu" e o tempo passivo do "mim" não se confundem, coexistem na unidade da pessoa. Como vimos anteriormente, isso só é possível em razão da natureza reversível do signo, como a palavra.

$\mathrm{Na}$ realidade, estas reflexões não constituem uma grande novidade. A dupla condição do homem, ao mesmo tempo, sujeito e objeto de conhecimento foi, segundo Foucault (1992), o que permitiu o aparecimento desse novo campo do saber moderno que são "as ciências humanas". Essa condição de Homo Duplex já era objeto de especulação do pensamento filosófico e era conhecida da psicologia. A novidade está em que essa condição que o signo torna possível faz da pessoa, ao mesmo tempo, o cenário interior do drama das relações sociais e a consciência do drama que tem lugar nesse cenário onde ela desempenha múltiplos papéis diferentes e, freqüentemente, conflituosos. "A dinâmica da personalidade é drama", diz Vigotski, mas "um drama é sempre um confronto de conexões" (dever e afeto, paixão e controle, amor e ódio, confiança e ciúme etc.), "não pode ser diferente, ou seja, é um confronto de sistemas".

\section{Notas}

1. "The word history (historical psychology) for me means two things: (1) a general dialectical approach to things - in this sense, everything has its history; this is what Marx meant: the only science is history (Archives of Marx \& Engels); natural science = the history of nature, natural history; (2) history in the stricte sense, i.e., human history. The firts history is dialectical; the second is historical materialism [...] The uniqueness of the human mind lies in the fact that both types of history (evolution + history) are united (synthesis) in it." (1989, pp. 54-55, itálico do autor)

2. "The uniqueness of the human mind lies in the fact that both types of history (evolution + history) are united (synthesis) in it. The same is true in child psycholog." L. Vygotsky, Concrete...op. cit., p. 55.

3. O interesse que a pesquisa de Ivan P. Pavlov despertou em Vigotski está relacionado, principalmente, com o fato de que o "modelo da dupla estimulação" (resultado da descoberta por Pavlov do estímulo condicionado) abre uma pista metodológica para estudar a passagem das formas elementares de comportamento, comuns aos animais, às formas mais complexas específicas dos seres 
humanos. A idéia de um sinal que se interpõe como mediador na relação $E-R$ conduz Vigotski ao conceito de signo que, na primeira elaboração conceptual, é definido como "qualquer estímulo condicionado criado pelo homem que é um meio para controlar a conduta dos outros e a própria" (CW, 4, p. 54). Uma elaboração mais refinada do conceito de signo levará Vigotski à idéia de mediação semiótica, onde a palavra ocupa um lugar eminente. A evolução do pensamento do autor a respeito da função do signo na atividade produtiva do homem, ao lado do instrumento, o afasta definitivamente da tradição reflexológica que tinha em $\mathrm{V}$. M. Bekhterev e I. P. Pavlov seus principais representantes.

4. Pavlov, I. P., Obras Completas, vol. 4, Moscou, 1951, p. 30, citado pelo autor.

5. Cf. Feuerbach, L., L'Essence du Christianisme, Paris, Éd. François Maspero 1982; Manifestes Philosophiques, textos selecionados por L. Althusser, col. Épimethée, Paris, PUF, 1973

6. "Mais l'essence humaine n'est pas une abstraction inhérente à l'individu singulier. Dans sa réalité, c'est l'ensemble des rapports sociaux", Marx \& Engels, L'Ideologie Allemande, "Teses sobre Feuerbach", Paris, Ed. Sociales, 1982, p. 52.

7. Cf. Hegel 1941, onde fala da "consciência de si", especialmente pp. 145-166.

8. "Even in being transformed into mental processes, they (social relations) remain quasisocial."(CW, 4, p. 106) "In their own private sphere, human beings retain the functions of social interaction" Wertsch, "The Genesis", op. cit., p. 164.

9. "The telephone operator is the social personality of a person. A person as a member of a specific social group. As a definite social unit. As a being in itself -for others and for itself", "Concrete..." op. cit., p. 64.

10. "sleep acquired a regulatory function through the social significance of dreams [...] what he sees in his dreams, he will do. This is reaction of a person, and not a primimtive reaction. The relation of dream to future behavior (the regulatory functions of sleep) amounts genetically and functionaly to a social function [...] Then the social function is combined in one person". Concrete... op. cit., p. 65.

\section{Encaminhado para publicação em maio de 2000}

\section{The social and the cultural in Vigotski's work.}

ABSTRACT: This text constitutes of an analysis of two theoretical categories considered fundamental for an understanding reading of Vigotski's work: the social and the cultural. The text begins with the 1929 Manuscript, where the author outlines these questions, object of a latter elaboration. The meaning analysis that these categories have for Vigotski is done through the History concept proposed by the 
author, which shows the matrix that is the reference from his analyses: the historical materialism and dialectics. Analysed these two categories, two questions are discussed after them and that constitutes the central nucleus of the author's work: the social-cultural nature of the high mental functions which according to the author, they are social relationships internalized, and the semiotic mechanism that explains these social relations conversion in functions of the person.

\section{Bibliografia}

ALTHUSSER, Louis \& BADIOU, Alain. Materialismo histórico e materialismo dialético, trad. port. São Paulo: Global Editora, 1969.

FOUCAULT, Michel. As palavras e as coisas, São Paulo: Martins Fontes, trad. br. 1992.

HEGEL, G.W. Frederc. La Phénoménologie de l'Esprit, trad. de J. Hyppólite, 2 vol. Paris, Aubier: Montaigne, 1941.

KOJÈVE, Alexandre. Introduction à la lecture de Hegel, Paris: Gallimard, 1947.

MARX, Karl. Manuscrits de 1844, Paris: Sociales, 1972.

. Le Capital, 3 vol. Paris: Sociales, 1977.

MARX, Karl. \& ENGELS, Frederic. L'Ideologie Allemande, Paris: Sociales, 1996.

MILHAU, Jacques. "Introduction". In: MARX, Karl \& ENGELS, Frederic, L'idéologie allemande, Paris: Sociales, col. Essentiel, 1982.

PEIRCE, Charles S.. Semiótica, trad. bras. São Paulo: Perspectiva, 1990.

PINO, Angel. "A psicologia concreta de Vigotski: implicações para a Educação". Psicologia da Educação, São Paulo, 1999, 7/8, pp. 29-52.

. "Constituição e modos de significação do sujeito no contexto da pré-escola". Coletâneas da ANPEPP, Recife,1996, vol. 1, 4, pp. 11-32.

. "As categorias de público e privado na análise do processo de internalização". Educação \& Sociedade, 1992, n. 42, pp. 315-327.

. "A mediação semiótica em Vygotsky e seu papel na explicação do psiquismo humano". Cadernos Cedes, Papirus \& Cedes, São Paulo, 1991, n. 24, pp. 32-43. 
VYGOTSKY, Lev S. The Collected Works, 5 vol. N. York: Plenun Press, 1996-1998.

. "The genesis of Higher Mental Functions". In: WERTSCH, J. The concept of activivity in soviet psychology. N. York: M.M.Sharpe, 1981, pp. 144-185.

. "The socialist alteration of man". In: VAN DER VEER, R. \& VALSINER, J., The Vygotsky Reader, Oxford \& Cambridge, Blackwell, 1994, pp. 175-184.

. "The History of the Development of Higher Mental Functions". The Collected Works. N. York: Plenun Press, vol. 4, 1997. . "Concrete Human Psychology". Soviet Psychology. 1989, XXII, vol. 2, pp. 53-77.

VYGOTSKY,. Lev S. \& LURIA, R. "Alexandr Tool and symbol in child development". In: VAN DER VEER, R. \& VALSINER, J. (ed.), The Vygostky Reader, Oxford \& Cambridge, Blackwell, 1994.

WALLON, Henri. De l'acte à la pensée. Paris: Flammarion, 1942. . “O papel do 'outro' na consciência do 'eu'”. In: Psicologia e Educação da Infância, trad. port. Lisboa: Estampa, 1975, pp. 149-179.

WERTSCH, James V. The concept of activivity in soviet psychology, New York: M. M. Sharpe,1981. 